\title{
Dormancy Interferes with Flowering in Perennial Plants with Short Day Regulation of Both Processes: A Mini-Review
}

\author{
Ola M. Heide1 ${ }^{1}$ Anita Sønsteby ${ }^{2 *}$ \\ ${ }^{1}$ Department of Ecology and Natural Resource Management, Norwegian University of Life Sciences, Ås, Norway \\ ${ }^{2} \mathrm{NIBIO}$, Norwegian Institute of Bioeconomy Research, Ås, Norway \\ Email: ${ }^{*}$ anita.sonsteby@nibio.no
}

Received 17 June 2015; accepted 14 August 2015; published 17 August 2015

Copyright @ 2015 by authors and Scientific Research Publishing Inc.

This work is licensed under the Creative Commons Attribution International License (CC BY).

http://creativecommons.org/licenses/by/4.0/

(c) (i) Open Access

\section{Abstract}

In many perennial woody plants growing in the temperate and cold regions, regulation of seasonal growth cessation and floral initiation are closely integrated, both taking place in photoperiods shorter than a critical length. In the temperate shrub black currant (Ribes nigrum L.), the two processes proceed harmoniously in parallel under naturally decreasing autumn photoperiods, whereas an abrupt shift to photoperiods well below the critical length results in an immediate growth cessation and premature dormancy. As a result, floral initiation is suppressed and arrested. Other perennial plants such as hop (Humulus lupulus), which have the same dual short day responses, behave in the same way. In such plants, optimal flowering takes place at near-critical photoperiods, which are short enough to induce flowering and still long enough to prevent premature dormancy. These responses deviate from the situation in annual plants, which have predominated in studies on photoperiodic control of flowering. Another example of linkage between flowering and dormancy responses is the well-known dual effects of chilling temperature on vernalization and its relation to dormancy. Elucidation and disentangling of these networks of integrated processes are now awaiting joint research efforts in the areas of molecular genetics and experimental plant physiology.

\section{Keywords}

Black Currant, Dormancy and Flowering, Hop, Perennial, Photoperiod

\footnotetext{
${ }^{*}$ Corresponding author.
}

How to cite this paper: Heide, O.M. and Sønsteby, A. (2015) Dormancy Interferes with Flowering in Perennial Plants with Short Day Regulation of Both Processes: A Mini-Review. Agricultural Sciences, 6, 778-782. 


\section{Introduction}

Seasonal plant development is regulated and fine-tuned by complex regulatory networks of integrated processes controlled by seasonal environmental signals (e.g. [1]). Prominent among these signals are photoperiod and temperature, which independently, or by close interactions, synchronise plant development with seasonal changes in the environment [2]. By the concerted action of these and other external signals, and their mediation through specific genetic, biochemical and physiological processes, plant development from seed to seed is completed in harmony with seasonal changes in the plant growth environment. Through evolution and genetic manipulations and selections by man, numerous species-specific modifications of the general regulatory pattern have developed to establish an amazing array of diverse adaptations. For perennial plants living in cold environments, timely seasonal regulation of dormancy induction and release is crucial for plant survival of cold winters. Similarly, many plants have developed strategies for seasonal synchronisation of flowering to increase their chances of successful cross-pollination and to secure timely seed development in marginal growing seasons. Commonly, the same seasonal signal may be controlling several rather diverse processes that need to be carefully reconciled in order to avoid complicating interferences between processes of contrasting nature.

\section{Examples of Interference between Dormancy and Flowering Induction}

Black currant (Ribes nigrum L.) is a temperate shrub that is widely grown in temperate regions of both hemispheres as an important horticultural soft fruit crop. It is a short day (SD) plant that initiates flower primordia in the autumn in photoperiods shorter than a critical length over a wide range of temperatures [3]-[5]. Floral induction is also closely associated with induction of growth cessation and bud dormancy. Under naturally decreasing autumn photoperiods, floral initiation is consistently preceded by decreasing shoot growth, which is followed by complete growth cessation. In most cultivars, the critical photoperiods for the two successional processes are approximately 17 and $16 \mathrm{~h}$ [5] [6]. However, although black currant plants thus behave as regular SD plants with induction of flowering at photoperiods shorter than a critical length, (cf. [2]), flowering does not increase in the usual way at photoperiods shorter than the near-critical length of $15 \mathrm{~h}$. In fact, a large share of black currant plants (10\% - 50\% depending on the cultivar) did not initiate flowers at all at the presumed optimum SD of $10 \mathrm{~h}$, even after 8 weeks of exposure [5]. Also, whether expressed as number of flowers per plant, or as percentage of flowering nodes, flowering was always optimal at 14 - $15 \mathrm{~h}$ photoperiods, and decreased at both shorter and longer day-lengths (Figure 1). In a sense, this is the characteristics of so-called intermediate day length plants, which are sometimes classified as a specific group of photoperiod-sensitive plants [2]. The superior flowering at the near-critical photoperiod of 15 h compared with the presumed optimum day-length of 10 h was fully confirmed in further experiments [7]. It was also demonstrated that plants exposed to naturally decreasing daylengths in early July, produced significantly more flowers than plants transferred to natural day-lengths later in

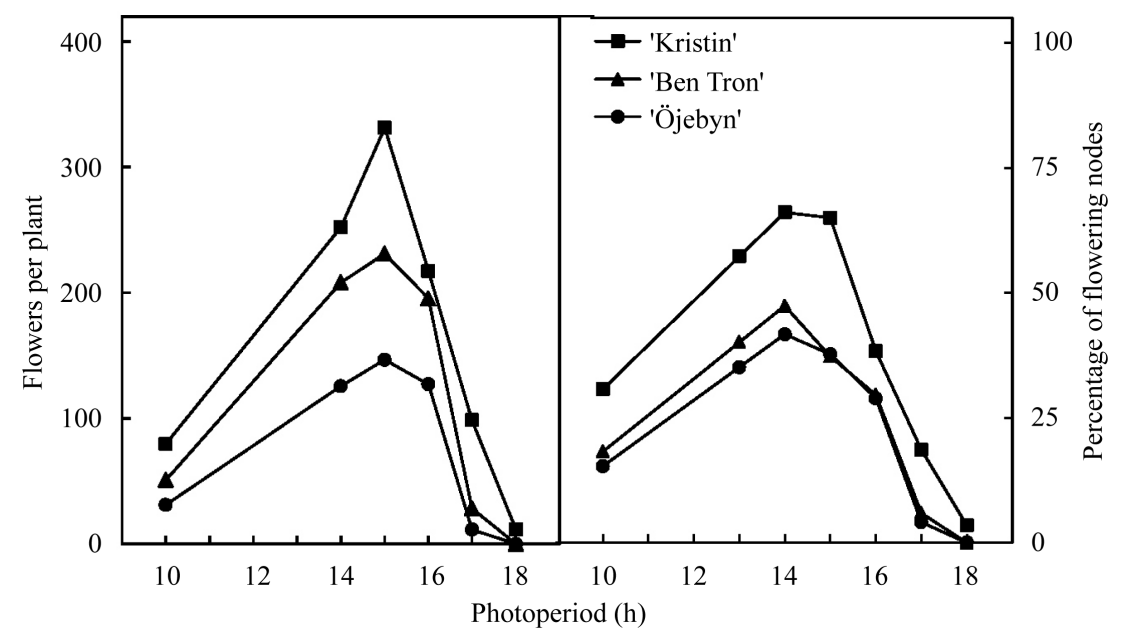

Figure 1. Flowering responses of three commercial black currant cultivars exposed to different photoperiods at $18^{\circ} \mathrm{C}$ for eight weeks. Each value is the mean of three replicates with three plants each. After [5]. 
the season when the photoperiod had decreased further. Furthermore, plants exposed to controlled photoperiods gradually decreasing from $15 \mathrm{~h}$ to $10 \mathrm{~h}$ responded in much the same way as plants in constant $15 \mathrm{~h}$, while the reverse change from $10 \mathrm{~h}$ to $15 \mathrm{~h}$ mimicked the response to constant $10 \mathrm{~h}$ photoperiod. In other words, the flowering response was determined by the photoperiod prevailing during the early phase of induction. Superior flowering was always associated with a gradual reduction in growth rate, while the sparse-flowering plants exposed to 10-h photoperiod consistently exhibited an early and abrupt cessation of growth [5] [7].

Thomas and Schwabe [8] [9] reported analogous responses for the hop plant (Humulus lupulus L.), a perennial plant that initiates flower primordia in photoperiods shorter than 15.5 - $16.5 \mathrm{~h}$, depending on the cultivar. As in the black currant, SD also induces cessation of growth and dormancy in hop plants. The number of flowers initiated varies with the length of the photoperiod, the optimum photoperiod being just below the critical one. With shorter photoperiods, the number of initiated flowers decreases progressively, until eventually, a single flower is formed in plants that has become prematurely dormant. This is exactly the same responses as those reported for black currant. To make the analogy complete, both black currant [4] and hop plants [8] [9] have a juvenile-like stage and must attain a certain shoot size before they are able to flower. Because of this, flower initiation in both species is prevented and delayed until after midsummer [8] [10], thus avoiding premature dormancy and flowering by SD early in the growing season.

Essentially the same unusual flowering response was recently reported for marsh cinquefoil plants (Potentilla palustris (L.) Scop.), a close relative of the strawberry [11]. This is a short-long-day plant that is induced to flower in SD but needs a transition from SD to LD for the actual initiation of flower primordia. As in black currant and hop plants, not only flowering, but also dormancy, is induced by SD in this plant. Likewise, the SD flower induction response was also optimal at near-critical photoperiods, in this case $16 \mathrm{~h}$, the number of flowers decreasing progressively at both shorter and longer photoperiods [11].

Although all these three species technically qualify for the classification as intermediate daylength plants, the underlying interference with dormancy renders such a classification rather artificial. The rationale for maintaining intermediate day length plants as a specific and genuine flowering response group has been seriously challenged also for other reasons [12].

\section{Molecular Relations}

In the winter-annual Arabidopsis, photoperiodic control of flowering is mediated by a genetic pathway in which CONSTANS (CO) and FLOWERING LOCUS T (FT) are major regulatory genes [13]. In perennial plants, however, the regulation of flowering is usually closely integrated with the annual growth cycle as reviewed by [14] and discussed for three perennial species above. In aspen (Populus), genes homologous to the CO/FT regulatory module control the timing of both flowering and seasonal growth cessation [15] [16]. Furthermore, the overexpression of Populus FT1 in plum trees, rendered them unable to enter dormancy and, at the same time caused continuous flowering [17]. It is not clear, however, whether the dual dormancy and flowering responses are parallel or sequential processes in these plants. In case of the three perennial species discussed above, induction of dormancy and flowering seems to be sequential processes following in close succession, the fate of the latter being influenced by the strength of the former [9] [5] [11]. In these species, the optimum photoperiod for floral induction must be short enough to allow flower initiation and still long enough to prevent premature dormancy. Under gradually decreasing photoperiods in the natural environment, the two processes proceed in harmonious order, whereas an abrupt shift to photoperiods well below the critical length induces an immediate cessation of both vegetative and reproductive growth. As a result, floral initiation is arrested in its infancy. In annual plants, however, which have predominated in studies on photoperiodic control of flowering [18] [19], such dormancy interference complications do not occur. In the classical perennial SD plant strawberry (Fragaria $x$ ananassa Duch.), such complications are also circumvented, probably because only a semi-dormant state is induced by SD in this species [20]. Thus, initiation of both leaf and flower primordia proceeded unimpeded in SD strawberry cultivars under continuous SD conditions [21]. It is thus clear, that dormancy interference with flowering, as described for some perennial species above, is not a common feature of all such perennial plants with SD control of both flowering and dormancy.

A related example of linkage between flowering and dormancy responses is the well-known dual effects of low temperature (vernalization) on flowering in cold-requiring plants and its relation to dormancy [22]. The ranges of effective temperatures are very similar for both vernalization and dormancy release, and in both cases, 
the temperature signal is perceived directly by the shoot apical meristem region [2]. Again, although both developmental phenomena have been known for more than a century, our understanding of their causal interrelationship is still rather fragmented.

\section{Conclusions and Future Perspectives}

In some perennial plants in which SD regulation of flowering and seasonal growth cessation is closely integrated, flowering can be severely compromised by simultaneous induction of premature dormancy. In such plants, nearcritical photoperiods are optimal for flowering, because they are short enough to allow flowering and still long enough to prevent premature dormancy. Further, molecular genetics and developmental plant physiology studies are now needed to elucidate and unravel the integrated regulation of the processes involved.

\section{References}

[1] Wellmer, F. and Riechmann, J.L. (2010) Gene Networks Controlling the Initiation of Flower Development. Trends in Genetics, 26, 519-527. http://dx.doi.org/10.1016/j.tig.2010.09.001

[2] Thomas, B. and Vince-Prue, D. (1997) Photoperiodism in Plants. 2nd Edition, Academic Press, London.

[3] Nasr, T.A.A. and Wareing, P.F. (1958) Photoperiodic Induction of Flowering in Black Currant. Nature, $182,269$. http://dx.doi.org/10.1038/182269a0

[4] Tinklin, I.G., Wilkinson, E.H. and Schwabe, W.W. (1970) Factors Affecting Flowering in the Black Currant. Journal of Horticultural Science, 45, 275-282.

[5] Heide, O.M. and Sønsteby, A. (2011) Critical Photoperiod for Short-Day Induction of Flowering in Black Currant (Ribes nigrum L.). Journal of Horticultural Science \& Biotechnology, 86, 128-134.

[6] Sønsteby, A., Opstad, N. and Heide, O.M. (2012) Effects of Summer Temperature on Growth and Flowering in Six Black Currant Cultivars (Ribes nigrum L.). Journal of Horticultural Science \& Biotechnology, 87, 157-164.

[7] Heide, O.M. and Sønsteby, A. (2015) Simultaneous Dormancy Induction Interferes with Short Day Floral Induction in Black Currant (Ribes nigrum L.). Scientia Horticulturae, 185, 228-232. http://dx.doi.org/10.1016/j.scienta.2015.02.002

[8] Thomas, G.G. and Schwabe, W.W. (1969) Factors Controlling Flowering in Hop (Humulus lupulus L.). Annals of Botany, 33, 781-793.

[9] Thomas, G.G. and Schwabe, W.W. (1985) Humulus lupulus. In: Halewy, A.H., Ed., Handbook of Flowering, Vol. III. CRC Press, Boca Raton, FL, 167-172.

[10] Sønsteby, A. and Heide, O.M. (2013) Variation in Seasonal Timing of Flower Initiation in Black Currant (Ribes nigrum L.) Cultivars of Contrasting Geographic Origin. Journal of Horticultural Science \& Biotechnology, 88, 403-408.

[11] Heide, O.M. and Sønsteby, A. (2015) Flowering Physiology and Cold Resistance of Potentilla palustris (L.) Scop., a Wild Relative of the Strawberry. Journal of Horticultural Science \& Biotechnology, 90, 235-244.

[12] Heide, O.M. (2004) Dual Induction Rather than Intermediate Daylength Response of Flowering in Echinacea purpurea. Physiologia Plantarum, 120, 298-302. http://dx.doi.org/10.1111/j.0031-9317.2004.0228.x

[13] Searle, I. and Coupland, G. (2004) Induction of Flowering by Seasonal Changes in Photoperiod. EMBO Journal, 23, 1217-1222. http://dx.doi.org/10.1038/sj.emboj.7600117

[14] Kurokura, T., Mimida, N., Battey, N.H. and Hytönen, T. (2013) The Regulation of Seasonal Flowering in the Rosaceae. Journal of Experimental Botany, 64, 4131-4141. http://dx.doi.org/10.1093/jxb/ert233

[15] Böhlenius, H., Huang, T., Charbonnel-Campaa, L., Brunner, A.M., Jansson, S., Strauss, S.H. and Nilsson, O. (2006) CO/FT Regulatory Module Controls Timing of Flowering and Seasonal Growth Cessation in Trees. Science, 312, 1040-1043. http://dx.doi.org/10.1126/science.1126038

[16] Hsu, C.Y., Adams, J.P., Kim, H., No, K., Ma, C., Strauss, S.H., et al. (2011) FLOWERING LOCUS T Duplication Coordinates Reproductive and Vegetative Growth in Perennial Poplar. Proceedings of the National Academy of Sciences of the United States of America, 108, 10756-10761. http://dx.doi.org/10.1073/pnas.1104713108

[17] Srinivasan, C., Dardick, C., Callahan, A. and Scorza, R. (2012) Plum (Prunus domestica) Trees Transformed with Poplar FT1 Results in Altered Architecture, Dormancy Requirement, and Continuous Flowering. PLoS ONE, 7, e40715. http://dx.doi.org/10.1371/journal.pone.0040715

[18] Evans, L.T. (1969) The Induction of Flowering: Some Case Histories. Macmillan, Melbourne.

[19] Bangerth, K.F. (2009) Floral Induction in Mature, Perennial Angiosperm Fruit Trees: Similarities and Discrepancies with Annual/Biennial Plants and the Involvement of Plant Hormones. Scientia Horticulturae, 122, 153-163. http://dx.doi.org/10.1016/j.scienta.2009.06.014 
[20] Guttridge, C.G. (1985) Fragaria x ananassa. In: Halevy, A.H., Ed., Handbook of Flowering, Volume III, CRC Press, Boca Raton, 16-33.

[21] Sønsteby, A. and Heide, O.M. (2006) Dormancy Relations and Flowering of the Strawberry Cultivars Korona and Elsanta as Influenced by Photoperiod and Temperature. Scientia Horticulturae, 110, 57-67. http://dx.doi.org/10.1016/j.scienta.2006.06.012

[22] Chouard, P. (1960) Vernalization and Its Relation to Dormancy. Annual Review of Plant Physiology, 11, 191-238. http://dx.doi.org/10.1146/annurev.pp.11.060160.001203 